\title{
THE ROLE OF A WRITER: REFLECTIONS OF A NOVELIST
}

\author{
Prabhu Ray Yadav"
}

\begin{abstract}
Chinua Achebe is an iconic name in Africa as well as world literature. He is a writer committed to the social uplift of marginalized and downtrodden people. He believes that serious writer should have a sense of responsibility to enhance the quality of humanity by way of exposing all manmade suppression and oppression in society. Achebe is a crusader against colonialism that enslaved the African countries and their people. He is opposed to the injustice and atrocities perpetrated by colonial rulers, and he wants to awaken the African people to rise up against the onslaught of colonialism in future. The present work serves as an inspiring guide to the African people and writers to pursue the spirit of struggle to gain self dignity and recognition. He writes with a missionary zeal and exhorts the writers to use their art as a weapon to assert their confidence and past glory. For him, art is a means to bring about change in society. His works have served as a teacher for his readers. So, Achebe has become a novelist cum teacher, especially for African people, and in general for his readers all over the world.
\end{abstract}

Key words: Art, culture, role, writer, pen, instrument, eradicate, poverty, literacy, social political, refinement, imbibe, nullify, vengeance, onslaught.

\section{INTRODUCTION AND OBJECTIVE}

Chinua Achebe, one of the most distinguished Nigerian writers, was born on 16th November 1930, in Ogidi. He had held several offices as a Controller, Director, Researcher and Visiting Professor. He was a teacher at the University of Nsukka, Nigeria. Achebe is one of the most highly regarded of African writers in English. His greatest strength as a novelist is the steady refinement of his control over language. His stories deal with the social and political problems facing his country, including the difficulty of the post colonial legacy. Achebe's (1965). "The Novelist as Teacher" is a talk delivered at the first Common Wealth Writers' Conference at Leeds in 1964. Art and Culture of the society should always entertain as well as instruct. According to him, the writer is an organic part of the society. Therefore, he requests the fellow African writers to advise the future generation through their art of writing. Each and every writer should have the social responsibility in order to eradicate poverty and illiteracy.

* Mr. Yadav is Lecturer in English, Patan Multiple Campus, Patan Dhoka, TU. 


\section{THE ROLE OF A WRITER: REFLECTIONS OF A NOVELIST}

Achebe maintains that each and every society in the world has its own needs and beliefs. He pinpoints modern European song writer as a "divine administrator of vengeance" for writing a pop song entitled I Ain't Gonna Wash for a Week. The African society builds a separate identity as against the Western identity.

Achebe (1969), a self conscious writer and committed artist, has stated: "most of my readers are young. They are either in school or college or have only recently left. And many of them look up to me as a kind of teacher" (p. 42). He believes that modern African writers should teach rather than impress the readers. He states in his essay "Novelist as Teacher" "... I would be quite satisfied if my novels (especially the ones I set in the past) did no more than teach my readers that their past ... on God's behalf delivered them" (p. 72). A writer has more responsibility to shape the social and moral values of the society. The nature and art must be pure. Achebe (2010) argues that art is important, but so is education. The two must go hand in hand. He has noted in his essay 'The Novelist as Teacher' that African people lost their self - respect in the colonial period, and it is this dignity that they must now regain. So, he specially stated that the role of a writer in modern Nigeria is to write about the contemporary issue of why the rights have been denied for African people in their own home land.

\section{Beauty of art and education}

In "The Novelist as Teacher", Achebe himself is a sort of missionary who uses his pen as an instrument to educate the people. He takes this great task to enlighten the readers and he also succeeded. But it is only fitting that the novelist be considered one of the most important types of teacher today. Achebe (1982) stresses in his essay that the duty of a writer is to teach and educate the society. He tries to depict the history of pre-colonial Ibo culture to the present day youths. He believes in art. Art must be pure and can bring about change in the society. Pen is the only powerful weapon that should always tell the truth without hesitation and misrepresenting. Achebe (2013) feels that his current society should get rectified from the post-colonial sentiment through his novels. His first novel Things Fall Apart shows the culture and colonial power in his community.

This article aims to highlight the role of the African writers in search of equality in comparison with the Western writers. African writers encounter with the rich and intellectual writers of the Western culture exposing their pride and prejudice. Achebe's writing encourages African writers to acknowledge their own culture and society. Such thoughts of Achebe enrich his readers with new vigour and strength. This paper focuses on the following objectives: 
- To think about the upright and moral duty of the writer(s) for the sake of people and society,

- To make readers aware of the real events and situations as essential components of true art and knowledge,

- To develop a sense of alertness about the beauty of culture and society,

- To empower the readers to grasp the importance of culture and its beauty for the education of society.

\section{METHODOLOGY}

The methodological approach in this paper is based upon Edward E. Said's conception which insists on a comprehensive dismantling of colonial hierarchies and structures. It requires an enlightened intellectual consensus which expresses itself in favour of the larger, more generous human realities of community among cultures, peoples, and society, ( $p$. 162). In other words, the intellectual stirrings of anti colonialism as reflected in Achebe's (1997) writing can only be properly realized when nationalism becomes more "critical of itself - when it proves itself capable of directing attention to the abused rights of all oppressed classes" (p. 264).

\section{The passionate lover for community}

A writer should achieve something from his work either in directing the society to the right path or enlightenment. N. P. White says: "Knowledge is truth, Truth is knowledge"(p. 146). Achebe also wishes that his country people should get proper knowledge of the universe. The Ibo community people are ready to believe anything that comes to them. He says that whatever he writes it is related to the people of his own community. Likewise, it is done in all the countries by the best writers. He also wants to display to the readers that Africans are not brutal as myths portrayed in the colonial period. Another misconception that Achebe sets out is to rectify the language spoken by the Ibo tribe. He calls his fellow African writers to dedicate themselves to their society. Achebe works hard not only to broaden the world of art and literature, but to lead his community people to the modern world. When he visited Mysore, in India once, the Dalit activist took him to the Dalit colonies. He was very disturbed at the sight of the condition in which the Dalit lived and said that in Africa it was considered sin if the blood of God's children was spilled on the ground but here the blood of Dalits was considered as virtuous to spill on the mother earth. Most of his novels linger in the minds of readers especially of college going students. It shows his passionate love of his community and tradition of his country. 


\section{THE ROLE OF A WRITER: REFLECTIONS OF A NOVELIST}

Achebe's orientation in Africa has been recognized that art is in the public domain, a sense of social commitment is mandatory upon the artist. $\mathrm{He}$ is not only showing just matters but also re-orients the society. He advised that the writers must rise to teach and by doing so can help the society to regain belief in itself and put away complexes of the years of denigration and self-abasement. The novel or any writings must be effective. It should not affect the people instead people should know the effect of it. Writers' work must instruct or re-direct the perceptions of people about a particular thing. Art is always pure so that the readers prefer to read it from any angle he or she chooses. After reading he or she gets pleasure, while for others it is a lesson. Sometimes beauty is seen, some will appreciate it. Achebe is the best story teller; all types of readers can enjoy his novels. Achebe (2013) in Things Fall Apart he used ornamental words as given below:

The drums beat and the flutes sang and the spectator held their breath. Analyze was a willy craftsman, but Okonkwo was as slippery as a fish in water. Every nerve and every muscle stood out on their arms, on their thighs, and one almost heard them stretching to breaking point. In the end Okonkwo threw the cat. (p. 3)

This plot is expressed with too much of background explanations. So, he portrays every scene to the readers as a reality show. When he describes the year, he says: "That year the harvest was sad, like a funeral, and many farmers wept as they dry up the miserable and rotting yams. One man tied his cloth to a tree branch and hanged himself" (p. 17). This shows the natural reaction of the character Okonkwo.

\section{Lagos' word 'Like'}

Atta's (2005) novel published in twentieth century is "Everything Good Will Come". She sets her novels for Non-Nigerians, to teach Nigerian sociology. Atta breaks up the narrative to explain to her audience how the word, 'like' is used in Lagos: 'In Lagos we used the word 'like' this way. You liked to stare, you liked to criticize, you liked to make appointments and not keep them. There was an assumption, bad English aside, that if you did something often, you liked it' (p. 151). Her foreign audience will benefit this sense how the Africans are imperfect user of English. She has beautifully written about the patriarchal society.

Achebe explains about the caste based prejudice prevailing in Nigeria in his the story Marriage is a Private Affair:

The prejudice against Nnaemeka's marriage was not confined to his little village. In Logos, especially among his people who worked there, it showed itself in a different way. Their women, when they 
met at their village meeting, were not hostile to Nene. Rather, they paid her such excessive difference as to make her feel she was not one of them. But as time went on, Nene gradually broke through some of this prejudice and even began to make friends among them. Slowly and grudgingly, they began to admit that she kept her home much better than most of them. (p. 181)

In Arrow of God, the third novel of Achebe (1969) talks about political and cultural activities around the villages. The disaster of Igbo society is portrayed in such a way that it will lead not only to the assimilation of western values and beliefs but also the loss of the Igbo cultural identity. Carroll celebrates 'Achebe's Flexible use of English to demonstrate Igbo modes of speech and thought' (Carroll 1970). His inordinate love of that word itself should be of interest to psychoanalysts. Sometimes his fixation on blackness is equally interesting because Achebe wants to eradicate racism in western society. He reveals that writers alone can change the society by using effective method of writing in an honest way. He wants that the writer must always be passionate over his works.

'The Novelist as Teacher' reveals that the artists must have been given full freedom in writing through their conscience. Achebe's writings influence the readers. He wants the readers, especially in a country like Nigeria to understand how the British and the European people are considered superior to them. They must be made aware through reading some great African writers. He thinks the writers should not imagine as the counterparts of the Europeans and behave like them (Killam, 1973).

The writers must have close relationship with the readers. Most of the readers of Achebe are youngsters. These youngsters treat him as their teacher and good guide. Moreover, they believe that his novels help to solve the social problems. The students should regard his novels not just as novel but should treat them as holy books. They give high honour and would not treat them as mere entertainer. Therefore, the writer can be free to express his individual ideas. In such a way, Achebe realizes his part very clearly. 'Negritude' is a new coinage describing the African Black's feelings and attitudes. He argues that art is powerful, useful, and valuable to this unique world. We, the world writers, must take knowledge and expose it to the people in the world.

\section{CONCLUSION}

Chinua Achebe, in his essay The Novelist as Teacher, requests African writers not to deviate from ethics and their moral responsibility as teachers in their lives and works. This essay has two different meanings. 
Achebe, on the other hand, approaches the literature of postcolonial and western writers. On the other, he wants to acquaint himself with his audience as a teacher of society and culture. The Western writers highlight their culture and reiterate their common concerns. Achebe views social inferiority as the major product of the orientation to Western literature. Achebe's writings probe into repressed minds. The post colonial writers are urged to convey Achebe's message affirmatively in their works and writings. Achebe shows how Western writers propagate their culture in the world literature for the promotion of their own cultural knowledge and values. The African writers, on the other hand, are immune to the charge of propagating their culture. The Western writers serve as leaders to promote the cultural knowledge of propagating their own people. Achebe presents the Western writers as being respectful to their literature rather than the world literature. Achebe further argues that the Western culture and literature seek to nullify others' literature.

While African beliefs are strong, post colonialism has imposed inferiority complex upon the culture of the people. Achebe wants to build confidence in his country and people so that they become proud of their culture. Expressions like anti- racist racism are Achebe's strategy to uplift the African people and their culture. With African writers imbibing the positive power of ethnocentrism, the people gain the confidence to infuse their old mind set with that of the new world.

\section{WORKS CITED}

Achebe, C. (1965). English and the African writer. London: Heinemann Books.

--- (1977). An image of Africa. United States: Massachusetts University Press.

--- (1969). Arrow of God. New York: Anchor Books.

--- (2010). Flax-golden tales: Marriage is a private affair. Kathmandu: Ekta Books.

--- (1982). Morning yet on creation day: Essay. London: Heinemann Books.

--- (2013). Things fall apart. UK: Penguin Books.

Atta, S. (2005). Everything good will come. United States: Interlink Book.

Carroll, D. (1970). Chinua Achebe: Novelist, poet, critic. New York: Twayne Press.

Killam, G. D. (1973). The role of the writer in a new nation: African writers on African writing. London: Northwestern University press. 